Г. В. Давиденко

\title{
ЗАСОБИ ВИРАЖЕННЯ КОМПОНЕНТІВ СТРУКТУРИ АРХЕТИПУ ГЕРОЯ НІМЕЦЬКОЇ НАРОДНОЇ ПОБУТОВОЇ КАЗКИ
}

Давиденко Г. В. Засоби вираження компонентів структури архетипу героя німецької народної побутової казки.

У статті розкрито засоби вираження компонентів структури архетипу героя німецької народної побутової казки, інтерпретовано структурні компонентів архетипу героя німецької побутової казки як представника німецької культури. Встановлено, що кожен 3 компонентів співвідноситься 3 провідними національними концептами, які характеризують героя казки та його дії, а відтак - і представника німецького народу.

Ключові слова: національний архетип героя казки, німецька народна побутова казка, дискурс казки.

(ㄷ Г. В. Давиденко, 2013. 
Давиденко А. В. Способы выражения компонентов структуры архетипа героя немецкой народной бытовой сказки.

В статье раскрыто способы выражения компонентов структуры архетипа героя немецкой бытовой сказки, интерпретировано структурные компоненты архетипа героя немецкой бытовой сказки как представителя немецкой культуры. Установлено, что каждый из компонентов соотносится с ведущими национальными концептами, которые характеризуют героя сказки и его действия, а таким образом - и представителя немецкого народа.

Ключевые слова: национальный архетип героя сказки, немецкая народная бытовая сказка, дискурс сказки.

Davydenko H. V. Structure components of German household folk-tale hero's archetype methods of expression.

The thesis deals with the methods of expression of structure components of German household folk-tale hero's archetype, the structural components of German household folktale hero's archetype as representative of the German culture are interpreted. It is established that each of the components is correlated with the leading national concepts which characterize a folk-tale hero and his actions as the German people's representative.

Key words: a national folk-tale hero's archetype, German household folk-tale, tale discourse.

У пропонованій статті об’єктом нашої уваги є персонажі німецької народної побутової казки (коротких оповідань усної народної творчості на побутову тематику, зафіксованих братами Грімм зі збереженням оригінальної форми, змісту та звучання), предметом - засоби вираження компонентів структури архетипу героя німецької народної побутової казки. Наша увага спрямована на встановлення й інтерпретацію структурних компонентів архетипу героя німецької побутової казки як представника німецької культури. Національний архетип героя казки - це історично опрацьовані архетипні уявлення, соціокультурне втілення модифікованого архетипу в особистості [6, с. 236].

Протагоніст казки є продуктом культури суспільства, вираженням єдності багатьох індивідуальних потреб та інтересів. Триєдність соціального ідеалу, утіленням якого є герой побутової казки, можна представити як єдність істини, добра і краси. Характер культури залежить від того, яка зі сторін триєдності соціального ідеалу в ній домінує. Оскільки персонаж $є$ персоніфікацією різних семантичних сфер, він наділений ознаками, що реалізують відразу кілька аспектів значення.

Архетип героя німецької побутової казки є складним утворенням, яке має багатоаспектний характер i не має єдиного витлумачення. Він складається $з$ семи компонентів, кожен із яких вирізняється властивими лише йому ознаками: 1) типи героїв за характером здійснюваних дій: геройшукач, герой-жертва, герой-хазяїн, герой біблійних історій; 2) атрибутивні характеристики героя: позитивний / негативний; 3) належність до одного зі світів (реальний, світ вищих сил, міфічний); 4) герой як втілення певної моральної ідеї: у світі панує зло; доля мінлива; видимість оманлива; 
пристрасті згубні; задовольняйся тим, що $є ; 5)$ герой як носій визначених функцій: дії, які він здійснює (дієслово-концепт); місце дії (дім, населений пункт, поле, ліс, земля, небо); 6) мотиви, що лежать в основі певних дій героя; 7) типи героїв за розробкою тем: професійні типи; соціальні типи; легендарні типи) [2, с. 123-130].

Інтерпретація архетипу героя німецької народної побутової казки сприяє встановленню особливостей національного менталітету. Художні образи персонажів казок є носіями концептуальної інформацї [3, с. 13].

Персонаж німецької народної побутової казки відтворює у своєму образі сторони життєвої реальності. Відображаючи реальний світ у казках, етнос керується властивим лише йому баченням світу, переломлює його крізь призму своєї творчої свідомості і структуру мови, створюючи неповторний індивідуальний художній світ. Цей художній світ складає словесну структуру дискурсу [4, с. 249].

У понятті «архетип» ми виділили сім основних компонентів (семантичних полів), кожен із яких має специфічні ознаки. Підраховуючи частотність уживання варіантів, що відповідають ознакам одного семантичного компонента, ми переводимо якісні характеристики в кількісні, надаючи ознаці семантичного поля кількісну визначеність. Таке дослідження передбачає етапи: 1. Визначення предмета дослідження. 2. Установлення компонентів предмета дослідження (логічна операція). Сукупність виокремлених компонентів продемонструє систему показників досліджуваного явища. Кількість компонентів залежить від природи і складності відповідного об’єкта дослідження. 3. «Вимірювання» відібраних компонентів. У межах цього етапу здійснюється аналіз кількісної визначеності компонентів як сукупності кількісних характеристик їх ознак задля встановлення відомої субординації між компонентами.

Для отримання вихідних кількісних даних дібраний матеріал зі 101 німецької народної побутової казки піддано частотному аналізові за сімома компонентами у структурі архетипу героя.

Відповідно до отриманих результатів можна зробити такі узагальнення: а) типи героїв за характером здійснюваних дій: Sucher (герой-шукач) 14 (велетень, чорт, смерть, солдат, розбійник, швець, кравець, кухарка, праля, пастух, мисливець, купець, санітар, лікар); Held der Kinderlegenden (герой біблійних історій) - 3 (Бог, Діва Марія, апостоли); Opfer (геройжертва) - 2 (селянин, служник); Hausherr (герой-хазяїн) - 1 (селянин); б) атрибутивні характеристики героя: Gut (позитивний) - 13 (Бог, Діва Марія, апостоли, солдат, селянин, швець, кравець, праля, пастух, мисливець, купець, санітар, лікар); Вӧsе (негативний) - 5 (велетень, чорт, розбійник, служник, кухарка); Gerecht (справедливий) - 1 (смерть); в) належність до одного зі світів: Erdreich (реальний світ) - 13 (солдат, селянин, розбійник, служник, швець, кравець, куховарка, праля, пастух, мисливець, купець, 
санітар, лікар); Jenseits (світ вищих сил) - 5 (чорт, смерть, Бог, Діва Марія, апостоли); Fabelwelt (міфічний світ) - 1 (велетень); г) герой як втілення певної моральної ідеї: Das Schicksal ist abänderbar (Доля мінлива) 11 (солдат, селянин, швець, кравець, кухарка, праля, пастух, мисливець, купець, санітар, лікар); Es dabei bewenden lassen (Задовольняйся тим, що є) 5 (Бог, Діва Марія, апостоли, селянин, служник); Böse herrscht auf der Welt (У світі панує зло) - 4 (велетень, солдат, селянин, розбійник); Leidenschaften sind unselig (Пристрасті згубні) - 2 (чорт, смерть); Das Äиßere trügt (Видимість обманлива) - 1 (розбійник); г) локалізація героя: Ortschaft (населений пункт): Stadt / місто - 9 (солдат, служник, швець, кравець, куховарка, праля, купець, санітар, лікар), Dorf / село - 1 (селянин); - Haus (дім) - 9 (чорт, селянин, розбійник, служник, швець, кравець, кухарка, праля, лікар); Wald (ліс) - 4 (велетень, чорт, розбійник, мисливець); Feld (поле) - 3 (велетень, селянин, пастух); Himmel (небо) - 3 (Бог, Діва Марія, апостоли); Gebirge, Berg (гори) - 1 (велетень); д) мотиви, що лежать в основі певних дій героя: бажання, спроби самоствердитись - 9 (солдат, селянин, швець, кравець, лікар, санітар, куховарка, праля, мисливець); бажання володіти чимось - 6 (велетень, чорт, смерть, розбійник, лікар, купець); бажання захистити - 4 (смерть, Бог, Діва Марія, апостоли); бажання привернути до себе увагу 2 (солдат, пастух); прагнення заявити про своє право на жалість - 2 (селянин, служник); е) типи героїв за розробкою тем: професійні типи - 9 (швець, кравець, кухарка, праля, пастух, мисливець, купець, санітар, лікар); соціальні типи - 4 (солдат, селянин, розбійник, служник); легендарні типи - 6 (велетень, чорт, смерть, Бог, Діва Марія, апостоли).

Кількісні показники ознак дають змогу представити ієрархічну організацію структури архетипу героя німецьких побутових оповідань. Для цього нам потрібно вирахувати чисельні значення стандартного відхилення ознак, величиною «Sx» 3 формули вираховування коефіцієнта кореляції Г. Корна [5, с. 84]. За цією формулою $\mathrm{Sx}=$ загальна сума $\left(\mathrm{x}-\mathrm{x}^{\prime}\right)^{2}$ / число ознак, де $\mathrm{x}-$ чисельний показник частотності одиниць, $\mathrm{x}^{\prime}-$ середнє арифметичне. Так, наприклад, компонент А) типи героїв за характером здійснюваних дій має 4 ознаки, середнє арифметичне х' буде дорівнювати 5; їхня загальна сума $\left(\mathrm{x}-\mathrm{x}^{\prime}\right)^{2}-110$; стандартного відхилення ознак $\mathrm{Sx}(\mathrm{A})=27,5$.

Показник цієї величини стає основним критерієм аранжування компонентів у структурі національного архетипу. Якщо розташувати компоненти в порядку від більшого показника до меншого, то можна вирахувати ієрархію організації архетипу героя німецької побутової казки:

а) типи героїв за характером здійснюваних дій - 27,5

б) атрибутивні характеристики героя $-24,77$

в) належність до одного зі світів - 24,77

г) герой, як втілення певної моральної ідеї - 12,24 
г) локалізація героя - 9,46

д) мотиви, що лежать в основі певних дій героя - 7,65

е) типи героїв за розробкою тем $-4,2$

Дискурс німецької народної побутової казки є особливою системою комунікації, «символічною моделлю, яка формує людський досвід - як пізнавальний, так і емоційний» у розв'язанні найважливіших проблем буття. Основа комунікації в побутовій казці - передавання життєво важливих для людини і суспільства моральних смислів [1, с. 142]. Це відображено в запропонованій ієрархії архетипу героя побутової казки як представника німецького етносу.

Схема «герой-шукач, герой-жертва, герой-хазяїн, герой біблійних історій» є персоніфікацією генетичної пам'яті народу, де зафіксовано ставлення до релігії, землі, природи та відповідні національні характеристики. Перше місце компонента «характер здійснюваних дій» у структурі архетипу зумовлене тим, що в дискурсі народної побутової казки вихідний набір характеристик є очевидним, а їхні модифікації в героях порівняно однотипними.

Компонент «атрибутивні характеристики» $є$ константою в дискурсі німецької народної побутової казки, що й забезпечує його друге місце у структурі архетипу героя казки. Не властива казці психологічна розробка характерів компенсується використанням постійних епітетів, які поділяють дійових осіб казки на позитивних і негативних.

Генетично пов'язані з анімізмом та тотемізмом образи героїв міфічного світу та світу вищих сил з об'єкта первісних вірувань перетворюються на естетичні артефакти, створюючи форми ненаукового розуміння світу людиною. Вищі сили стають способом вираження суспільної оцінки, носіями колективних уявлень про соціальну справедливість як про суспільну норму. Такими обставинами визначається третє місце компонента «належність до одного зі світів» у цій ієрархії.

Компонент «моральна ідея» демонструє те, що ментальна установка героя побутової казки, а відтак - i німця, визначається передусім бажанням жити в достатку.

Компонент «локалізація» в казці позначається через місце дії, отже, через місце проживання німця, що має важливе значення для німецького народу внаслідок історичних особливостей формування німецького етносу.

Компонент «мотиви, що лежать в основі дій героя». Вони завжди $\epsilon$ складними і являють собою не просто збіг обставин чи набір стійких сюжетних функцій, а виступають однією з головних причин існування героя в казці. Те, що спонукає актанта до дії, безпосередньо пов'язане 3 загальною тематикою та прагматикою дискурсу побутової казки.

Дослідження лексичних одиниць, які характеризують героя казки та його дії, дали змогу з'ясувати, чому утворилася така послідовність в (С) Г. В. Давиденко, 2013. 
ієрархії архетипу героя казки. Кожен із компонентів співвідноситься 3 провідними національними концептами, які характеризують героя казки та його дії, а відтак - і представника німецького народу. Компонент «локалізація» втілюється в концепті HAUS (ДIM); компоненти «моральна ідея», «характер здійснюваних дій» та «мотиви, що лежать в основі дій героя» характеризуються такими концептами, як ORDNUNG (ПОРЯДОК), ARBEIT (ПРАЦЯ) та SPARSAMKEIT (ОЩАДЛИВIСТЬ). КонцеПти DAS GUTE (ДОБРО) i DAS BÖSE (ЗЛО) знаходять своє вираження в компонентах «атрибутивні характеристики» та «належність до одного зі світів». У подальшому можливе дослідження лексичного наповнення кожного компонента в межах інтерпретації змісту того чи того лінгвокультурного концепту.

\section{Література}

1. Бацевич Ф. С. Основи комунікативної лінгвістики : [підручник] / Ф. С. Бацевич. К. : Видавничий центр «Академія», 2004. - 344 с.

2. Давиденко Г. В. Німецька народна побутова казка: тематичні, структурнокомпозиційні та лінгвокультурні характеристики : дис. ... канд.. філол. наук : 10.02 .04 / Г. В. Давиденко. - К., 2008. - 208 с.

3. Єсипович К. П. Образ «Чарівного» у французькій народній казці (лінгвокогнітивний аспект) : автореф. дис. ... канд. філол. наук : спец. 10.02.05 «Романські мови» / К. П. Єсипович. - К., 2006. - 20 с.

4. Кожинов В. В. Об изучении художественной речи / В. В. Кожинов // Контекст. M., 1975. - C. 249-267.

5. Корн Г. Справочник по математике для научных работников и инженеров : Определения. Теоремы. Формулы / Г. Корн, Т. Корн ; [пер. И. Г. Арамановича (ред. пер.) и др.]. - СПб. [и др.] : Лань, 2003. - 831 с.

6. Юнг К. Г. Психология бессознательного / Карл Густав Юнг. - М. : АСТ : Канон+, 1998. - 397 с. 